
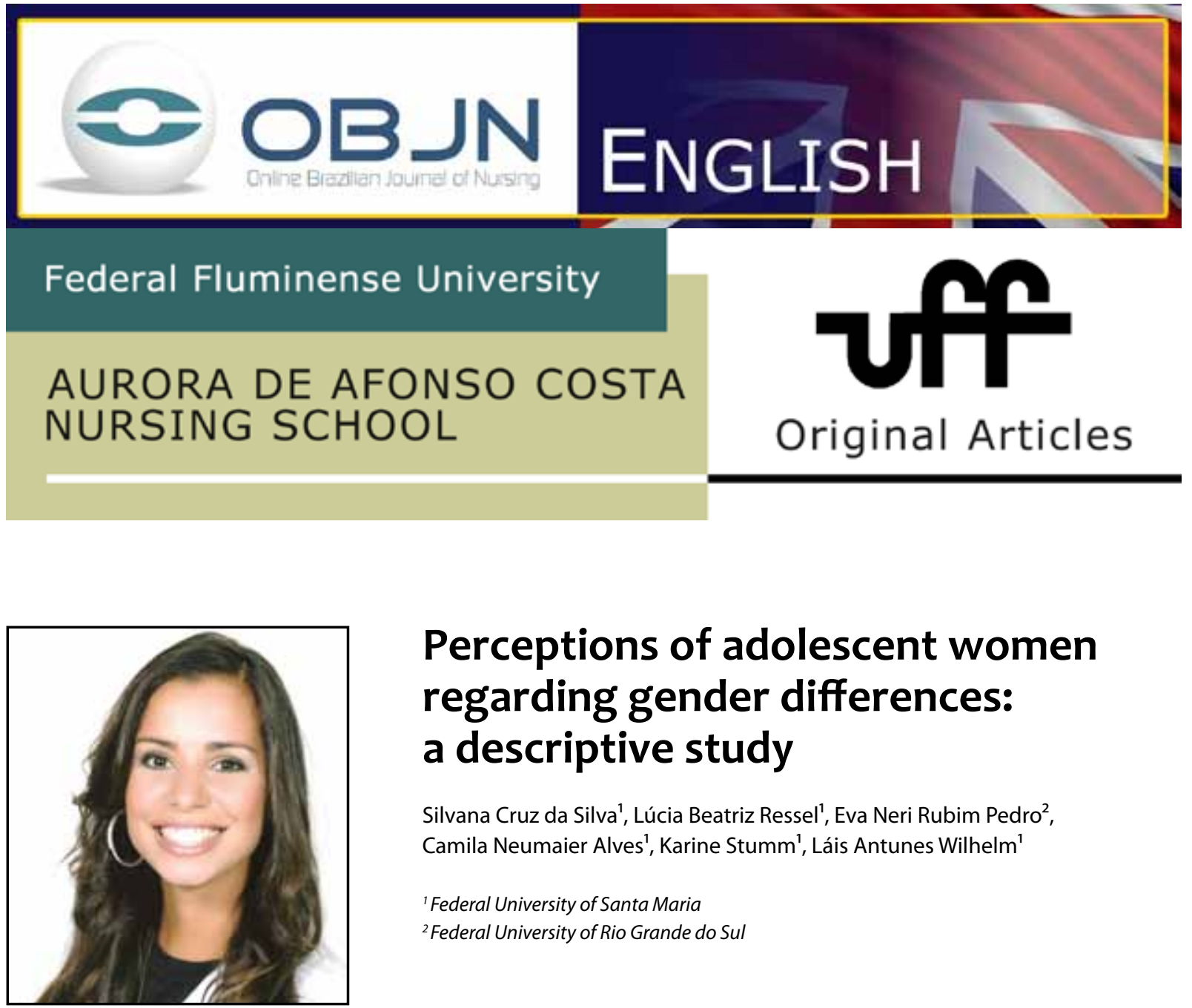

\title{
Perceptions of adolescent women regarding gender differences: a descriptive study
}

\author{
Silvana Cruz da Silva', Lúcia Beatriz Ressel'1, Eva Neri Rubim Pedro², \\ Camila Neumaier Alves ${ }^{1}$, Karine Stumm¹, Láis Antunes Wilhelm ${ }^{1}$ \\ ${ }^{1}$ Federal University of Santa Maria \\ ${ }^{2}$ Federal University of Rio Grande do Sul
}

\section{ABSTRACT}

Aims: To understand the perceptions and meanings of being an adolescent woman in our society and to reflect upon the sociocultural construction of these women. Method: This is a field descriptive study, in which a qualitative approach was used, carried out in a public school in Rio Grande do Sul. Nine adolescent women participated in the study. Data collection occurred in June and July 2012 by means of focus groups. For data analysis we used thematic analysis. Result: Relations that teenagers have about sexuality, their condition as women, and the treatment they receive from family and society have emerged. Discussion: Great influence of gender on sexuality was found, and it was confirmed that adolescents bring their practices based on their socio-cultural backgrounds and relationships with regard to gender inequality, prejudice and social hierarchy. Conclusion: It is important for nurses to know the meanings attributed by adolescents to issues such as gender and sexuality, so that nurses can contribute to effective and contextualized strategies.

Descriptors: Women's Health; Adolescent Health; Gender Identity; Sexuality; Nursing. 


\section{INTRODUCTION}

Attention to women's health, adolescent health and sexuality are strongly intertwined and associated with the process of the medical care of the female body, in the perspective of transformation, not only of groups and those in the public sphere, but also of individuals. In a social control context, the process of medicalization of the female body is extended to sexuality and reproduction, and it is decisive for transforming these aspects into objects of medical knowledge, due to the understanding that female nature is essentially maternal and reproductive ${ }^{(1)}$.

The medicalization of the female body is mainly reflected in the constraints related to women's autonomy over their bodies. However, this situation began to change in Brazil in the 1980s during the Sanitary Reform, along with the claims of the feminist movement ${ }^{(2)}$, leading to, in 1983, the Program for Integral Assistance to Women's Health (PAISM), created by the Ministry of Health. From 2004, this program has become politicised, and was renamed the National Policy for Integral Assistance to Women's Health (PNAISM). This change made evident the commitment to implementing health interventions for women, with the aim of guiding the services available to women, driven by the effectiveness of sexual and reproductive rights as part of human rights.

In this perspective regarding the expansion of health policies and actions, discussions about the uniqueness and the need for specific policies for teenagers were developed.

Thus, this study focuses on adolescent women, and it is justified by the realization that the process of becoming an adolescent, as experienced by them is, in most cases, characterized by the repression of their sexuality; the differentiation of behaviors and controls that impinge differently on men; by the "noes" aimed at the constant limitations; by the many prohibitions; by the notions of inferiority and passivity, among other constraints; as well as by the lack of dialogue and clarification of the biological, social and cultural events that are part of their lives ${ }^{(3)}$.

Sexuality is an essential characteristic of human beings, and it is present throughout the lives of individuals. In this study, it is understood that the construction of sexuality is both individual and collective, because it is expressed and is influenced by the context in which the subject lives. We may state that, during the different stages of life, human beings express their sexuality uniquely and with different cultural influences, either from their families, groups of friends, or school $^{(4)}$.

Teenagers should be viewed in their entirety, with their own cultural identity, according to their time and space. To this end, we believe it is necessary for nursing professionals to rethink dominant cultural models to become reflective and critical, and which leads them, through care, to develop sensitivity, creativity and the skills of listening, seeing and feeling. Thus, the relevance of the proposed theme, both in terms of professional and academic practice, is clear, as the nurse has a transformative role to play in society, and should work for changes that will enable the improvement of the quality of the lives of users.

Based on the above, one can glimpse the guiding question of this study: what is the meaning, assigned to teenage women, of being a woman in our society? The outlined goal was to understand the perceptions and meanings of being an adolescent woman in our society, and reflect upon the sociocultural construction of these meanings. 


\section{METHOD}

This is a field descriptive study, in which a qualitative approach was used. The choice of this approach is justified because it allows the study of sociocultural influences which give support group investigations and social stories from the perspective of the actors ${ }^{(5)}$.

The research scenario was a small elementary public school in a municipality of the state of Rio Grande do Sul (RS), containing 303 students aged between six and 18 years.

The study included nine female adolescents, which is the ideal number of subjects (six to 15 ) to carry out the data collection technique used in this study, the focus group, in order to achieve the best possible interaction $^{(6)}$. In addition to providing greater group interaction, this condition facilitates the development of discussions, debates and intragroup communication.

Inclusion criteria were: being a teenage woman (between 12 and 18 years, according to the Statute of Children and Adolescents); a student of the school used in the study and; a resident in the study area. The exclusion criterion was: adolescents who have cognitive limitations that would preclude understanding and participating in the study.

The selection of subjects was intentional, according to the study objectives and guidelines for the focus group. The adolescents were invited to join the group, and their membership was voluntary. The invitations were made on three occasions to students in $5^{\text {th }}$ to $8^{\text {th }}$ grade classes, in which the adolescents were enrolled.

It is interesting to note that the focus groups were conducted with the same participants, and that there was only one withdrawal from the first to the second meeting, without prejudice to the research, and without replacement of the participant who had left.
Data were collected in June and July 2012 in three focus group meetings. The conversations were recorded and transcribed. These are defined ${ }^{(7)}$ as a kind of group discussion that values communication between the participants in order to generate data and help researchers to understand the different forms of communication that people use during interaction. It also clarifies the cultural values and norms of the group.

By means of this technique, the researcher can identify the knowledge shared by the group, which makes it a good method for collecting cultural data, particularly with regard to sensitive issues such as sexuality. In this sense, the focus group reveals dimensions of understanding that often remain unnoticed ${ }^{(7)}$.

For the organization of this research, the planning of the groups followed the theoretical guidance as to the operationalization of focus groups ${ }^{(6)}$, which consist of group composition and the tools and development of the focus group.

For data analysis, we used the thematic analysis type of content analysis ${ }^{(5)}$. This is defined as the discovery of meaning clusters, which constitutes communication in which the frequency or the presence of words, phrases or expressions have meaning for the analytical object. Therefore, for an analysis of meanings, the rise of certain topics denotes structures of relevance, reference values and behavior patterns that may be hidden in the speech ${ }^{(5)}$.

It was essential to adhere to ethical conduct throughout the process. For this purpose, we followed the rules of Resolution no. 466/12 of the National Board of Health, Ministry of Health, which govern research involving human subjects. The research began only after authorization from the school and from the Ethics Committee in Research, Federal University of Santa Maria, RS, of March 27, 2012 under the Opinion number 8931 and CAAE 00555212.2.0000.5346. 
The adolescents were informed about the research topic, its objectives and its implications for them. A form of consent, which is necessary for persons under 18 years of age was provided for their parents or guardians, and they signed it. The researchers signed a Confidentiality Agreement and the identity of the participants was hidden through the use of coded names in the form of fairy tale princesses.

\section{RESULTS}

For adolescents, there are different relationships between parents and sons and daughters, given that there is a greater control and regulation regarding the behavior of women. These differences in treatment were strongly highlighted in the comments:

I am the only daughter of my father and there is a great deal of difference. (...) With boys it is more liberal. They can do anything, right? (Rapunzel)

But for us, they interrogate us so much [...] my father says that women are crazy, that he doesn't understand them, that he doesn't understand any woman! (Ariel)

If we go out we have to answer where, when and with whom we are going out. [...], when my brother was little, my dad used to say that he had to date, and I would date only after I was 15 , but now that I'm 15 he says that I'm only dating when I turn 22. My mother, on the other hand, doesn't say that. She says the two of us can already date. (Fiona)
Certain naturalness can be observed while listening to deprecating and sexist comments about women, and it was noticed that some of these women end up repeating or agreeing with these statements.

Yeah ... some women are really crazy. (Yasmin)

Another difference pointed out by the adolescents in the group discussion relates to the punishment that parents foist differently on girls and boys, causing, thereby, differentiated control, in which they give women more freedom and show more aggressiveness towards men.

\footnotetext{
Like, my brother upsets and annoys my mom, and she just curses him, but if I do it, I can't go out. (Rapunzel)
}

I think that, for us, the punishments are more connected to other things. We can't stay up late at night, on the phone, on the computer; I don't know ... (Snow White)

I don't like having to stay home; it's a punishment to stay home. (Fiona)

They point to another difference in the relationship between male and female in terms of daily activities, in which boys have more options.

Because with the boys it's no use; everything they do is good; if they go outside it's cool! If they play soccer, it's okay. If they are prohibited from playing soccer... they will find something else to do... The girls, no... They don't have as many things to do as the boys. (Cinderella) 
Throughout the discussion group, at different times, it was possible to realize that there are family impositions concerning what can and cannot be done by women.

They always say that you can't do this or that because you are a kid, can't date because you are kid, can't go out alone because you are a kid. Oh! It sucks! (Bela)

He (brother) is my age, only four months older than me, but still he has more freedom than I do, he can do what he wants, and I can't. (Fiona)

My brothers can play on the computer more than the girls [...] Dad is the one who decides. (Pocahontas)

Because they are stronger, so we can't even come close to using it. (Cinderella)

Another aspect voiced by them was the concern about what "others" think or say regarding their attitudes and behavior:

[...] Even if we don't do anything wrong, the neighbors end up talking about it... (Bela)

[...] it's better being an adolescent man than a girl, because a man can go here and there, and do nobody talks about them. (Ariel)

[...] they give you nicknames, like "soap" just because you're on the street... (Fiona)

And that is wrong; the boys also go out ... (Pocahontas)
When asked about the reasons for these differences and where they come from, the participants answered that society is sexist:

It is because society is like this! (Yasmin)

... Because the world is sexist. (Bela)

It is so because he is a boy and the world is sexist, as has already been said. (Aurora)

Sexism is like this: the boy goes out and they don't care because it's a boy, but if the girl goes out, they say: "That one is always in the street..." (Cinderella)

Adolescents perceive media influence and prejudice regarding the vision that society has of women.

There are those old soap operas, you know? Now 'Gabriela' is being shown on TV. I don't know if you watch it, but, like, women's work is to take care of the man. Where did you get this from? While men can do nothing, do whatever they want... women have to be at home, taking care of her things and his. But men can be anywhere, because they know how to take care of themselves... (Rapunzel)

Yes, even today it happens! (Snow White)

One day I was watching TV with my family, and my uncle told me that women can only be in contact with the stove: 'for me a woman will just take care of me and my stove'. I thought it was the last straw! (Ariel) 
That's awful! It is ridiculous! (Cinderella)

\section{DISCUSSION}

It was clear from the adolescents' speeches that there was explicit differentiated treatment delivered to sons and daughters in the family. This resulted in the devaluation of parents' opinions regarding their experiences, in keeping greater control, and in the regulations of parents toward adolescents, in addition to smaller freedom in terms of girls' daily activities.

It is noted that the issues of gender and sexuality are distinct and inter-related fields, with a set of ideas concerning a shared culture, on which beings, in this case the adolescents and their parents, base their actions and worldviews, reproducing and recreating those conventions ${ }^{(8)}$, as seen in adolescents' speeches.

Thus, sexuality, largely influenced by gender relationships, can become significant dilemmas for adolescent women, and they end up affecting their choices and practices concerning care in terms of their sexuality, often making them more vulnerable, simply because of a gender issue ${ }^{(2)}$.

This study agrees with research in nursing that every teenager carries their practices, experiences, and their exercise of sexuality. This is based on their origins in terms of social class, family history, socialization, relations of equality and inequality experienced, sharing of prejudices and social hierarchy, among other processes of human subjectivity ${ }^{(9)}$.

The group indicated that, for girls, punishments are related to keeping them at home and forbidding them from doing things they like. As for the boys, punishments are more violent and aggressive. It is perceived that adolescents use values related to models of masculinity, associating violence and greater recreational possibilities with men. At the same time, they feel hampered by sanctions aimed at women. This finding is similar to those of another health study conducted with adolescent women ${ }^{(8)}$.

It was observed that activities like dating, going out alone, and even spending more time on the computer, were identified as practices in which boys have more freedom. It was also perceived that adolescent boys benefit from some activities due to differences in physical strength.

The different behavior of parents regarding raising their daughters and sons directly interferes with the formation of identity and with the attitude that these adolescents adopt in terms of sexuality. These manifestations and behavioral standards directed towards adolescent women directly affect their understanding and construction of their sexuality ${ }^{(3)}$.

For adolescent women, gender relations and sexuality are constructed with possibilities and delimited spaces that cannot be transgressed, under the penalty of being pressured and censored. An example is the reinforcement of the stereotypes of masculinity and femininity, which was also found in our study, in which what is experienced by adolescent women as losses, is seen as a gain for adolescent males. Such sociocultural patterns directly interfere with the power of women when it comes to making decisions ${ }^{(2)}$.

It is notable that the reinforcement of inequality in relationships between men and women hinders and increases the vulnerability of women in the safe exercise of their sexuality ${ }^{(8)}$. Therefore, many of them feel upset and report not seeking guidance from parents about their doubts and fears concerning sexuality, while still having their questions, or doing what they believe is the correct thing, sometimes placing themselves in situations of higher vulnerability.

The group was unanimous in the view that, even when they are not doing anything wrong 
or doing the same thing as boys, their attitudes generate nasty comments in the community because they are women. The adolescent women become uncomfortable with these situations, but do not stop doing what they think is right, or because they see there is nothing harmful in what they are doing.

We can see the ambivalence between what is regulated and what is practiced by adolescent women. For girls, differently from boys, sexuality is associated with the control of behaviors, and those who insist on transgressing the rules, deliberately and explicitly, suffer social sanctions on the basis of moral control by the group, in which case, they are spoken about in the neighborhood ${ }^{(8)}$.

It is worth reflecting that society often reproaches adolescents for their behavioral or sexual practices, emphasizing the success of such practices when they occur in other age groups; that is, in groups of adults, such practices are considered to be a mark of success ${ }^{(10)}$. In a way, this issue shapes adolescent behavior as such adolescents mirror themselves on adult groups. Concomitantly, controls and regulatory differences are reproduced between male and female adolescents.

The adolescents demonstrate an understanding that parents' and neighbors' attitudes towards them are not something that are isolated, but rather are a reflection of a culture which they define as sexist. It is noted in the comments made, that the understanding of chauvinism on the part of adolescent women is related to different behaviors and possibilities, beyond the judgments that are made of the same behaviors performed by people of different sexes.

We may infer from this study that the construction of sexuality is understood in terms of a gender dimension, highlighting differences and similarities between male and female, constructed socially and culturally. These data corroborate the study ${ }^{(11)}$ that features sexual practices and social organization as being linked to specific power devices with regard to certain times and certain societies.

We notice, in this approach, an approximation to Foucault's study on sexuality, which shows the existence of repression of sexuality throughout history, by means of a focus of attention on it, manipulated through speeches, creating power effects, forms of knowledge and pleasure control ${ }^{(12)}$.

The adolescent women in our study showed indignation and anger and stood together against the way soap operas address the role of women in society, and with regard to the sexist comments expressed in their families and social groups. They understand that women should not be submissive to their husbands; that they should have the same rights and the same conditions when it comes to taking care of themselves as men. However, it is noticeable that the values of the traditional patriarchal and sexist society are still transmitted to these adolescent women within their own homes.

Some historical changes about gender have been occurring in our society with regard to male and female roles and the position of women in this scenario. This can be seen in this study in terms of the indignant attitude of the adolescent women, in line with a study of nursing involving adolescents ${ }^{(13)}$.

The prejudicial attitudes of parents and the uncles of adolescent women reinforce the gender construction that assigns value to female submission, modesty and cautious attitudes, as well as control over women's bodies, which corresponds to another study on this subject ${ }^{(13)}$.

In this line of thinking, it is believed that teenagers need to be empowered to live their own lives with their own relationships, aware that they are being observed, and that society imposes stereotypical behaviors. It is also 
believed that issues of sexuality and gender promote norms, values, perceptions and representations that permeate the lives of subjects, legitimizing their identity and influencing their behavior. In this sense, gender identity is a matter of learning and working continuously, and not just an area of biological differentiation ${ }^{(14)}$.

It is believed, therefore, that it is necessary to introduce actions in terms of health education toward adolescents. This is an important professional strategy for the discussion, construction and exchange of knowledge. This knowledge should be based on respect and dignity and should welcome and establish a true bond, without prejudice to adolescent women ${ }^{(15)}$. Such actions must consider freedom, the right to be, and the responsibility for sexual experience, assisting adolescent women to form a critical awareness of the issue.

\section{CONCLUSION}

We clarify the understanding of adolescents in relation to their sexuality, their condition as women, and the treatment they receive from their parents and from society. In this study we found a great influence of gender on sexuality, since both are built from the primary socialization of individuals, and are strongly based on solid values that are culturally impinged differently with regard to women and to men. It was confirmed that adolescents base their practices on their socio-cultural backgrounds, as well as the relations of inequality, prejudice and social hierarchy.

Among the challenges of this research there is a commitment to the methodology of data collection. Working with groups is always a challenge, and is surprising and innovative. Yet, when it comes to health research, to the rigors of scientific method, it is very difficult to separate the nurse from the researcher, and sometimes, in conducting the focus groups, it was necessary.

In this direction, a broad spectrum of action is open to health professionals in terms of providing clarification with regard to doubts, and guidance to adolescent women. Action is also possible in terms of the possibilities of areas for discussion and for the exchange of consistent knowledge with regard to their difficulties and contexts, in order to qualify the experience of sexuality in adolescence and, therefore, in adulthood, in a healthier, more responsible, more confident and secure way.

When investigating female adolescence, there are no ready recipes, but rather paths that may or may not be suitable, since, even when a group is under the effect of the same cultural situations, every human being responds to the demands and opportunities of life in a unique and very personal way.

The implications of this study for nursing are related to the essence of the profession, which is that of care. When assisting and educating adolescent women, nurses should be aware of the meanings and perceptions that these adolescents have about their social roles as women, and their feelings and behaviors in relation to their sexuality. It is only with such a holistic view that nurses will be able to provide humanized care.

\section{REFERENCES}

1. Vieira EM. A medicalização do corpo feminino. Rio de Janeiro: FIOCRUZ; 2002.

2. Vargens OMC, Rangel TSA. Reflective analysis on the social aspects of HIV/AIDS: feminization, discrimination and stigma. Online Braz. J. Nurs. [internet]. 2012 April; [acesso em 2013 jan 11]; 18:[about \#\# p.]. Available from: http://www. objnursing.uff.br/index.php/nursing/article/ view/3531 
3. Ressel LB, Junges CF, Sehnem GD, Sanfelice C. A influência da família na vivência da sexualidade de mulheres adolescente. Esc Anna Nery (impr.). 2011 Abr; 15(2):245-250.

4. Fonseca AD, Gomes VLO, Teixeira KC. Percepção de adolescentes sobre uma ação educativa em orientação sexual realizada por acadêmicos(as) de enfermagem. Esc. Anna Nery (impr.). 2010 abr/jun; 14(2):330-337.

5. Minayo MCS. O desafio do conhecimento: pesquisa qualitativa em saúde. 12 ed. São Paulo: Hucitec-Abrasco, 2010.

6. Mazza VA, Melo NSFO, Chiesa AM. O grupo focal como técnica de coleta de dados na pesquisa qualitativa: relato de experiência. Cogitare Enferm. 2009 Jan; 14(1): 183-8.

7. Ressel LB, Beck CLC, Gualda DMR, Hoffmann IC, Silva RM, Sehnem GD. O uso do grupo focal em pesquisa qualitativa. Texto Contexto Enferm, Florianópolis, 2008 Out-Dez; 17(4): 779-86.

8. Taquette SR, Meirelles ZV. Convenções de gênero e sexualidade na vulnerabilidade às DSTs/ AIDS de adolescentes femininas. Adolesc. Saude. Rio de Janeiro. 2012 jul; 9(3): 56- 64.

9. Ressel LB, Sehnem GD, Junges CF, Hoffmam IC, Landerdahl MC. Representações culturais de saúde, doença e vulnerabilidade sob a ótica de mulheres adolescentes. Esc. Anna Nery Rev. Enferm. Rio de Janeiro; 2009 jul/set; 13(3): 552-7.

10. Coutinho MFG. Sexualidade na Adolescência. In: Pinto JAB, Cunha JB, Liberal EF, Vaconcelos MM. (Org.). Saúde Escolar. Rio de Janeiro: Guanabara Koogan; 1:97-102. 2012.

11. Ressel LB, Budó MLD, Junges CF, Sehnem GD, Hoffmann IC, Büttenbender E. The meaning of sexuality in nurse education. Journal of Nursing UFPE. Rio Grande do Sul. 2010;4(2).

12. Ribeiro MO. A sexualidade segundo Michel Foucault: uma contribuição para a enfermagem. Rev. Esc.Enf.USP. 1999 dez.; 33(4): 358-63.

13. Baggio MA, Carvalho JN, Backes MTS, et al. Significado do papel masculino/feminino para adolescentes. Esc Anna Nery. 2009 Out; 13 (4): 872-78.
14. Moura LBA, Reis PED, Faustino AM, Guilhem D, Bampi LNS, Martins G. Vivências de violência experimentadas por mulheres do distrito federal: estudo descritivo. Online braz. J. nurs. [periódico na Internet]. 2011 set-dez [cited jan 11 2013]; 10(3): [about \#\# p.]. Available from: http://www. objnursing.uff.br/index.php/nursing/article/ view/3534

15. Brasil EGM, Queiroz MVO, Cunha JMH. Receptiveness to the teenager in nursing consultation - a qualitative study. Online braz. J. nurs. [periódico na Internet]. 2012 Aug[acesso em 2013 jan 11]; 11(2):[about \#\# p.]. Available from: http://www. objnursing.uff.br/index.php/nursing/article/ view/3752

All authors participated in the phases of this publication in one or more of the following steps, in According to the recommendations of the International Committee of Medical Journal Editors (ICMJE, 2013): (a) substantial involvement in the planning or preparation of the manuscript or in the collection, analysis or interpretation of data; (b) preparation of the manuscript or conducting critical revision of intellectual content; (c) approval of the versión submitted of this manuscript. All authors declare for the appropriate purposes that the responsibilities related to all aspects of the manuscript submitted to OBJN are yours. They ensure that issues related to the accuracy or integrity of any part of the article were properly investigated and resolved. Therefore, they exempt the OBJN of any participation whatsoever in any imbroglios concerning the content under consideration. All authors declare that they have no conflict of interest of financial or personal nature concerning this manuscript which may influence the writing and/or interpretation of the findings. This statement has been digitally signed by all authors as recommended by the ICMJE, whose model is available in http://www. objnursing.uff.br/normas/DUDE_eng_13-06-2013.pdf

Received: 02/27/2013
Revised: 08/25/2013
Approved: 03/20/2014 